\title{
DYNAMICS OF ICE-ISLAND MOTION NEAR THE COAST OF AXEL HEIBERG ISLAND, CANADIAN HIGH ARCTIC
}

by

W.M. Sackinger, M.O. Jeffries, H. Tippens, ${ }^{*}$ F. Li, and M. Lu

(Geophysical Institute, University of Alaska-Fairbanks, Fairbanks, AK 99775-0800, U.S.A.)

\section{ABSTRACT}

The largest ice island presently known to exist in the Arctic Ocean has a mass of about $700 \times 10^{6}$ tonnes, an area of about $26 \mathrm{~km}^{2}$, and a mean thickness of $42.5 \mathrm{~m}$. Known as Hobson's Ice Island, this large ice feature has been tracked almost continuously since August 1983 with a succession of Argos buoys. In this paper, two particular iceisland movement episodes near the north-west coast of Axel Heiberg Island are described: 6-16 May 1986 and 14-21 June 1986. Each movement episode is analyzed in terms of the forces acting on the ice island, including wind shear, water drag, water shear, Coriolis force, sea-surface tilt, and pack-ice force. Ice-island movement is generally preceded by an offshore surface wind, and a threshold wind speed of $6 \mathrm{~m} \mathrm{~s}^{-1}$ appears to be necessary to initiate ice-island motion. An angle of $50^{\circ}$ between surface wind and ice-island movement direction is noted during one episode. The pack-ice force, which appears to be the dominant arresting factor of ice-island motion for these two episodes, varies from $100^{\circ}$ to $180^{\circ}$ to the left of the ice-island velocity direction, depending upon whether the ice island is accelerating or decelerating.

\section{INTRODUCTION}

The tabular icebergs of the Arctic Ocean, termed ice islands for the last four decades, are produced sporadically from the outer edges of the ice shelves off the north coast of Ellesmere Island (Fig. 1) (Koenig and others, 1952; Hattersley-Smith, 1963; Jeffries and Serson, 1983; Jeffries, 1986). These massive ice features usually drift initially towards the south-west, along the edge of the Canadian Arctic islands. Fragments and small ice islands have been observed along the coast of the Beaufort Sea (Spedding, 1977), where offshore oil production is planned to take place. Interactions of the ice islands with offshore structures are dependent upon the ice-island trajectories, and our research is aimed at assisting in both short-term and longterm prediction of such trajectories. An early description of the large-scale drift of ice island T-3 was given by Browne and Crary (1958), while Hunkins (1967) presented an analysis of the small-scale drift of T-3 when it was located far from shore in the central Arctic Ocean. In this paper we present an analysis of the drift of an ice island close to the ice-land boundary in the Canadian High Arctic.

In April 1983, a new cluster of ice islands was discovered soon after they had broken away from the Ward Hunt Ice Shelf (Jeffries and Serson, 1983). Since August 1983, when the cluster was seaward of Yelverton Bay, the position of the largest of the ice islands has been tracked nearly continuously with a succession of Argos buoys. A research station was established on the largest ice island by

*Present address: Jet Propulsion Laboratory, California Institute of Technology, Pasadena, CA 91109, U.S.A.

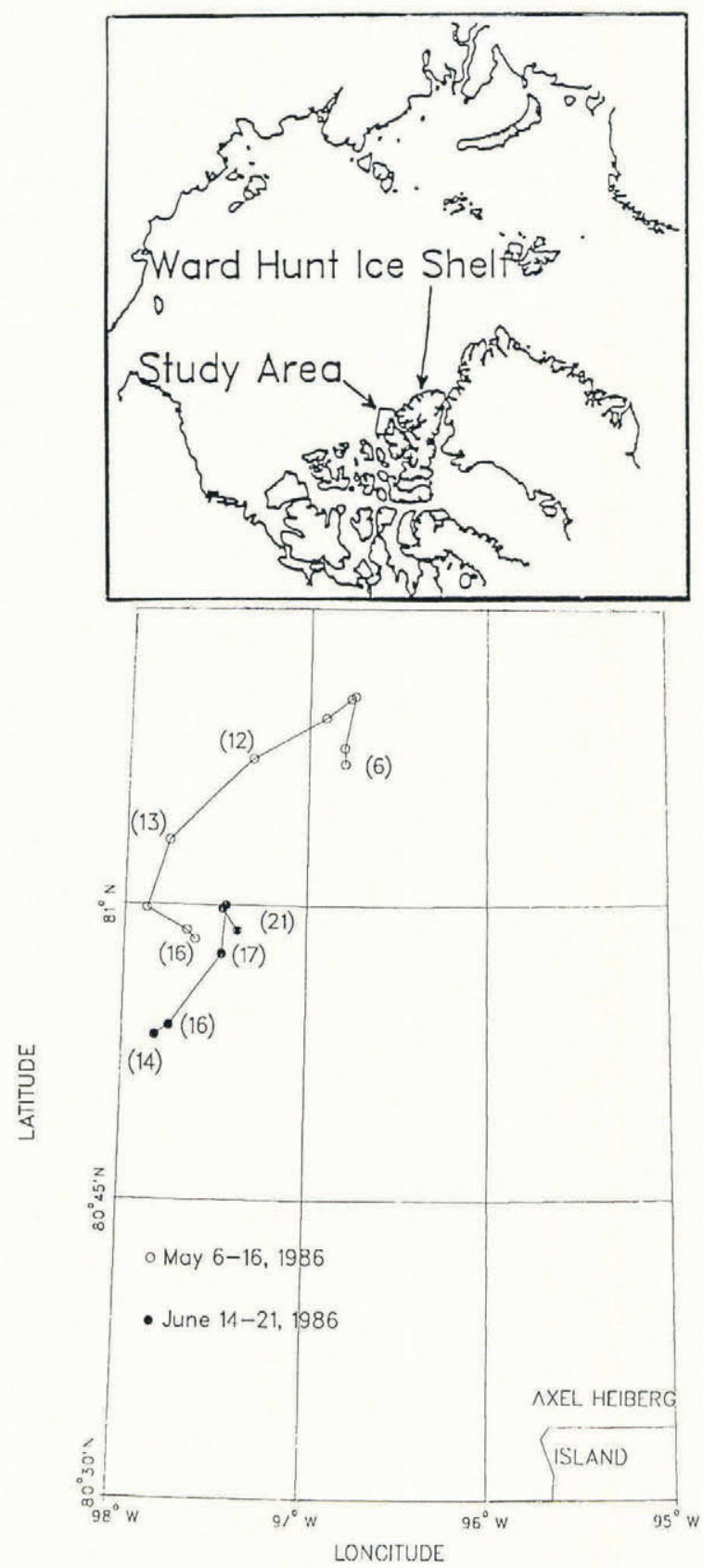

Fig. 1. Movements of Hobson's Ice Island for 6-16 May 1986 and 14-21 June 1986.

the Canadian Polar Continental Shelf Project in 1985, and we refer to this ice island as Hobson's Ice Island (Fig. 2). Five of the other ice islands were also instrumented with Argos buoys in 1985 and 1986, but their drift is not 


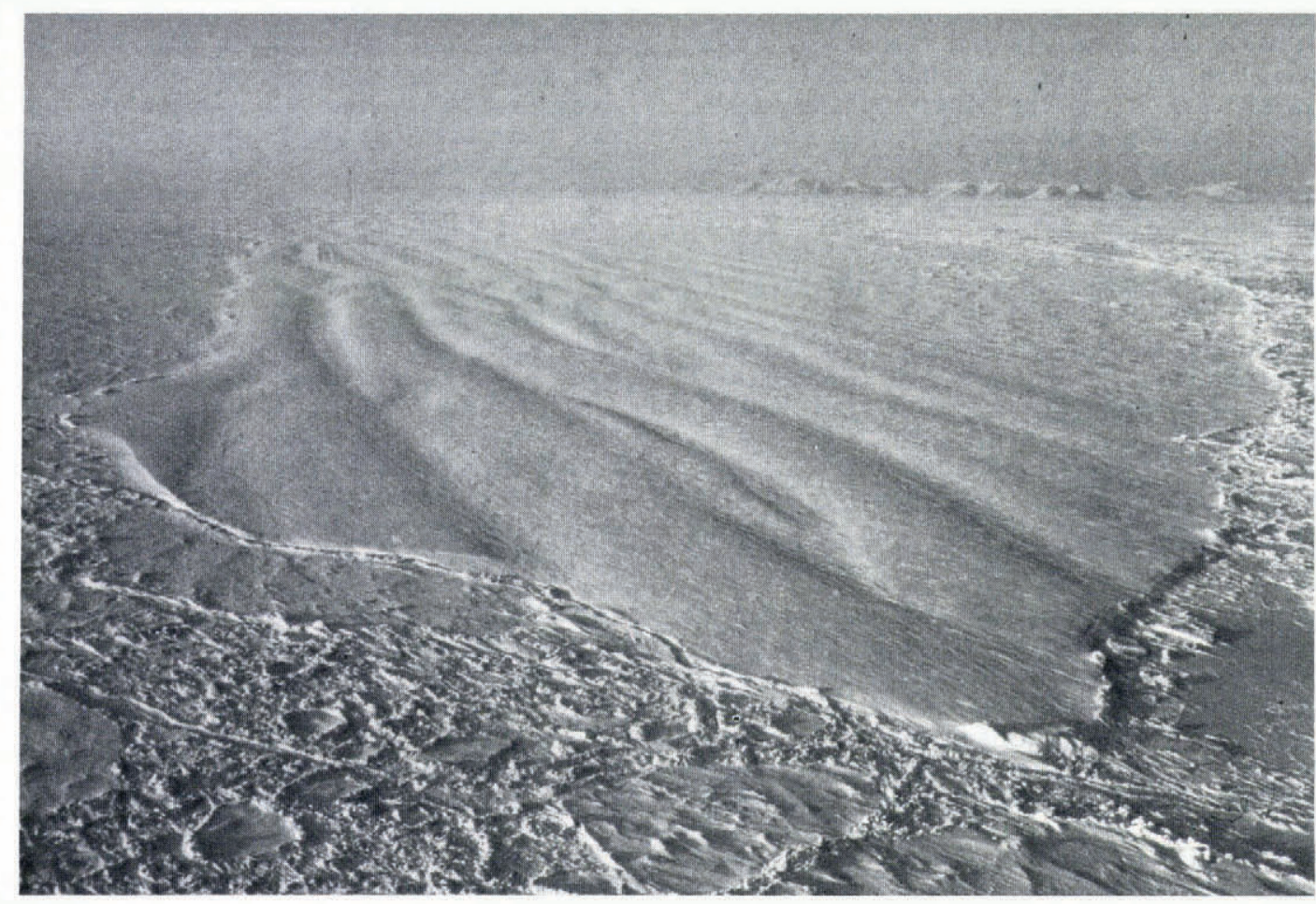

Fig. 2. Aerial view of the upper surface of Hobson's Ice Island, August 1987.

discussed here. Approximately 34 ice islands, varying in size from $4 \mathrm{~km} \times 9 \mathrm{~km}$ down to $500 \mathrm{~m} \times 500 \mathrm{~m}$, have been sighted, visually and/or on air photographs and radar imagery, in this Canadian High Arctic coastal region since 1983 (study area; Fig. 1) (Jeffries and others, 1988).

\section{ICE-ISLAND MOVEMENTS}

In the area from Cape Columbia to Sverdrup Channel (Ward Hunt Ice Shelf to study area; Fig. 1), the most common dynamic condition for both ice islands and pack ice is minor movements of less than $1 \mathrm{~km} / \mathrm{d}$, and of ten there is no detectable movement (Yan, unpublished). This has been ascribed to the prevailing winds of Arctic highs which confine pack ice against the Canadian shoreline (Yan, unpublished). The largest movements observed by Yan were parallel to the coastline, and were responsible for a net movement towards the south-west. Such episodes are infrequent (one to three times per year). To determine the wind force during large movement events, a surface windspeed and direction instrument was installed on Hobson's Ice Island in May 1986, and it operated successfully until midOctober 1986. Two notable movement episodes (6-16 May and 14-21 June 1986) took place during this interval while a doppler-satellite positioning system was simultaneously in operation at the ice-island research station camp. Trajectories for these episodes are shown in Figure 1. Position data were taken at $3 \mathrm{~h}$ intervals and are accurate to $\pm 30 \mathrm{~m}$ (Schmidt and others, in press). The wind speed and direction were taken at $2 \mathrm{~m}$ height at a location on the same ice island $3 \mathrm{~km}$ from the camp, and transmitted automatically through System Argos, together with barometric pressure and temperature. For conservation of battery life, the data transmitted by the weather station through System Argos were alternately on $4 \mathrm{~h}$ and off for $8 \mathrm{~h}$. No data were available on relative ocean currents beneath the drifting ice island.

\section{FORCES INVOLVED IN ICE-ISLAND MOTION}

The force equation for the observed sequence of transient movements of the ice island in the presence of nearly total surrounding sea-ice cover can be written as

$$
m_{\mathrm{ii}} \frac{\mathrm{d} \vec{V}_{\mathrm{ii}}}{\mathrm{d} t}=\vec{F}_{\mathrm{a}}+\left[\vec{F}_{\mathrm{ws}}+\vec{F}_{\mathrm{wp}}\right]+\vec{F}_{\mathrm{c}}+\vec{F}_{\mathrm{st}}+\vec{F}_{\mathrm{pi}}(1)
$$

where $m_{\mathrm{ii}}$ is ice-island mass, $\vec{V}_{\mathrm{ii}}$ is ice-island velocity, $\vec{F}_{\mathrm{a}}$ is wind-shear acting on the upper surface of the ice island, $\vec{F}_{\text {ws }}$ is water-shear force acting on the lower surface of the ice island, $\vec{F}_{\text {wp }}$ is water-drag force due to the frontal and rear areas of the submerged part of the ice island, $\vec{F}_{c}$ is Coriolis force, $\vec{F}_{\text {st }}$ is force due to sea-surface tilt, and $\vec{F}_{\mathrm{pi}}$ is pack-ice force acting on the boundary of the ice island. For Hobson's Ice Island, which is roughly rectangular in shape, the surface area $A_{\mathrm{S}}$ is $26.0 \mathrm{~km}^{2}$, the mass $m_{\mathrm{ii}}$ has been calculated to be $701.85 \times 10^{6}$ tonnes, and the island is composed of old ice shelf of thickness $42.5 \mathrm{~m}$ on one side, and newer ice shelf (also called multi-year land-fast sea ice, MLSI) of approximately $10 \mathrm{~m}$ thickness on the other side (Jeffries and others, 1988).

In calculations of forces acting on the ice island, the wind-shear force is given by

$$
\vec{F}_{\mathrm{a}}=\rho_{\mathrm{a}} C_{\mathrm{a}} A_{\mathrm{s}}\left|\vec{V}_{\mathrm{a}}-\vec{V}_{\mathrm{ii}}\right|\left[\vec{V}_{\mathrm{a}}-\vec{V}_{\mathrm{ii}}\right]
$$

where $\rho_{\mathrm{a}}=1.3 \mathrm{~kg} / \mathrm{m}^{3}$ is taken as the density of air, $C_{\mathrm{a}}=$ 0.0012 is the $10 \mathrm{~m}$ height air-drag coefficient over smooth ice (Pease and others, 1983), and $\vec{V}_{\mathrm{a}}$ is the velocity of the air. The very long wavelength undulations of the ice-island top surface (Fig. 2) are neglected in considering wind-shear force, as is the air-form drag due to the edges of the island above the water line. An extensive review (McBean, 1986) of air-drag coefficients has shown this value to be a good approximation for smooth, snow-covered ice, as is found on the top of the ice island. The drifting of snow into the ice-island/sea-ice edge region reduces air-form drag, hence our approximation there.

The water-shear force on the lower surface of the ice island is written as

$$
\vec{F}_{\mathrm{ws}}=\rho_{\mathrm{w}} C_{\mathrm{ws}} A_{\mathrm{s}}\left|\vec{V}_{\mathrm{w}}-\vec{V}_{\mathrm{ii}}\right|\left[\vec{V}_{\mathrm{w}}-\vec{V}_{\mathrm{ii}}\right]
$$

in which $\rho_{\mathrm{w}}=1.032 \mathrm{Mg} / \mathrm{m}^{3}$ may be taken as the density 
of sea-water, $C_{\mathrm{ws}}=0.00132$ is the drag coefficient for water under smooth horizontal, flat ice (Langleben, 1982) such as is believed to be typical of the under-water surface of this ice island, and $\vec{V}_{w}$ is the velocity of the water beneath the ice island. The geostrophic flow $\vec{V}_{\mathrm{w}}$ is due to sea-surface tilt, as discussed by McPhee (1982). Since the ice-island movement generally involves a sequence of transient events, as weather systems move through the region, the calculation of the local geostrophic water-flow velocity can be quite involved, and is beyond the scope of this paper.

An additional component of drag is due to the frontal area and the trailing area of the ice island. Adapting the results of Shirasawa and others (1984) for the form drag of a cube, one may write

$$
\vec{F}_{\mathrm{wp}}=\rho_{\mathrm{w}} h A_{\mathrm{f}}\left|\vec{V}_{\mathrm{w}}-\vec{V}_{\mathrm{ii}}\right|\left[\vec{V}_{\mathrm{w}}-\vec{V}_{\mathrm{ii}}\right]
$$

where $h=0.36$ (Shirasawa and others, 1984) and $A_{\mathrm{f}}$ is the frontal area of the wetted part of the ice island. The frontal area produces a large form drag. Although the direction of the water-drag force varies with time as the transient ice movements affect a changing volume of water, we have used the findings of McPhee (1982) for an angle of $24^{\circ}$ between the water-drag vector and the negative of the ice-velocity vector.

The Coriolis force $F_{\mathrm{c}}$ acts orthogonal to the ice-island velocity $V_{\mathrm{ii}}$, and with magnitude

$$
\left|\vec{F}_{\mathrm{c}}\right|=m_{\mathrm{ii}}[2 \Omega \sin \phi]\left|\vec{V}_{\mathrm{ii}}\right|
$$

where $\Omega$ is the angular velocity of the Earth and $\phi$ is the latitude. The mass of the ice island is much greater than that of an equivalent area of pack ice, causing the ice island to exert a larger force to the right of the direction of motion.

\section{MOVEMENT DETAILS AND DISCUSSION}

In Figure 3, the ice-island speed and direction for the May 1986 movement event are compared with the surface-
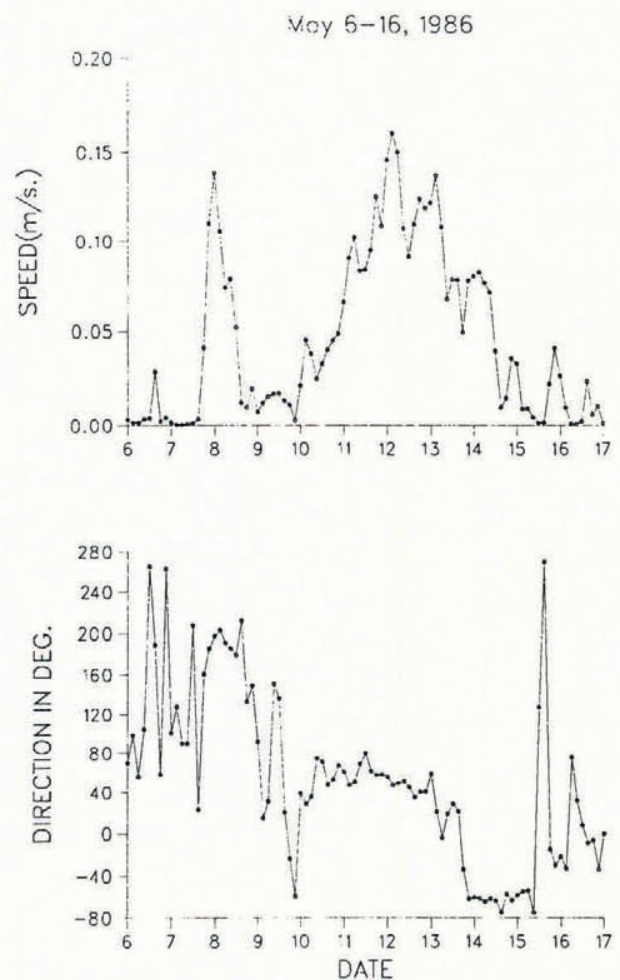

Fig. 3. Ice-island velocity and direction (left), compared with wind speed and direction (right), 6-16 May 1986.

wind speed and direction. Prior to the first substantial movement on 8 May, the low ice-island velocities toward the north were accompanied by surface winds which changed direction from the north to the east, and then to the south-east. Ice-island movement speed and direction details showed small fluctuations, perhaps of tidal origin, with a dominant but small northerly movement most likely caused initially by sea-surface tilt, and then by a combination of wind and Coriolis forces. The movement of the pack ice away from the shoreline permitted a more rapid ice-island movement episode from mid-day on 7 May until mid-day on 8 May, with the increase in wind speed from 4 to $9.5 \mathrm{~m} / \mathrm{s}$ nearly coincident with the ice-island speed increase from 0.35 to $13.89 \mathrm{~cm} / \mathrm{s}$ over a $9 \mathrm{~h}$ interval. On 8 May, the ice-island speed dropped rapidly over a $15 \mathrm{~h}$ interval, as the wind speed decreased from 9.5 to $6 \mathrm{~m} / \mathrm{s}$. Wind speeds were generally below $6 \mathrm{~m} / \mathrm{s}$ from 9 May to 11 May, with only minor associated ice-island movements; early on 10 May, a very brief $7.5 \mathrm{~m} / \mathrm{s}$ wind produced a corresponding $4.52 \mathrm{~cm} / \mathrm{s}$ velocity peak. Generally, wind speeds above $6 \mathrm{~m} / \mathrm{s}$, directed away from the shoreline, produced ice-island movement (Fig. 3).

The major sustained movement took place from 10 May at 12.00 U.T. to 14 May at 12.00 U.T., associated with a rise of wind speed to the $6.5 \mathrm{~m} / \mathrm{s}$ level over the (Fig. 3). A maximum ice-island speed of $16 \mathrm{~cm} / \mathrm{s}$ was observed on 12 May at 03.00 U.T. The superimposed small variations in ice-island speed are possibly due to tidal currents. The direction of ice-island motion is quite constant during the $3 \mathrm{~d}$ episode 10-13 May, as is the surface-wind direction (Fig. 3). The angle between the surface-wind vector and the ice-island velocity is $50^{\circ}$. The water-drag vector and the pack-ice force, the Coriolis force, and the sea-surface tilt may all contribute significantly during this episode.

The movement of the pack ice away from the shoreline, 6-10 May, permitted a relatively rapid movement parallel to the shore (10-14 May) with only a medium wind the surface-wind direction was substantially the same, with a slight drop in magnitude to the $4-5 \mathrm{~m} / \mathrm{s}$ range, but the abrupt drop in ice-island average speed, with a change in direction, and possibly a change in the periodicity of tidal currents, suggest that a change in sea-surface tilt may have moved the ice towards the shoreline beginning on 14 May.
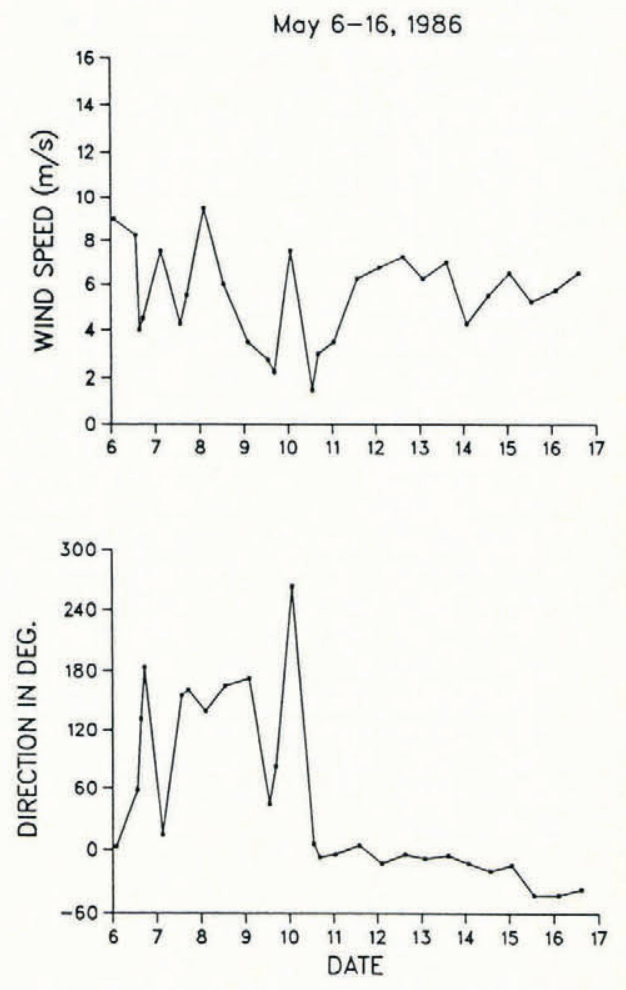
$24 \mathrm{~h}$ period, 10 May (12.00 U.T.) to 11 May (12.00 U.T.) intensity $(6.5 \mathrm{~m} / \mathrm{s})$. In contrast, from 14 May to 16 May, 

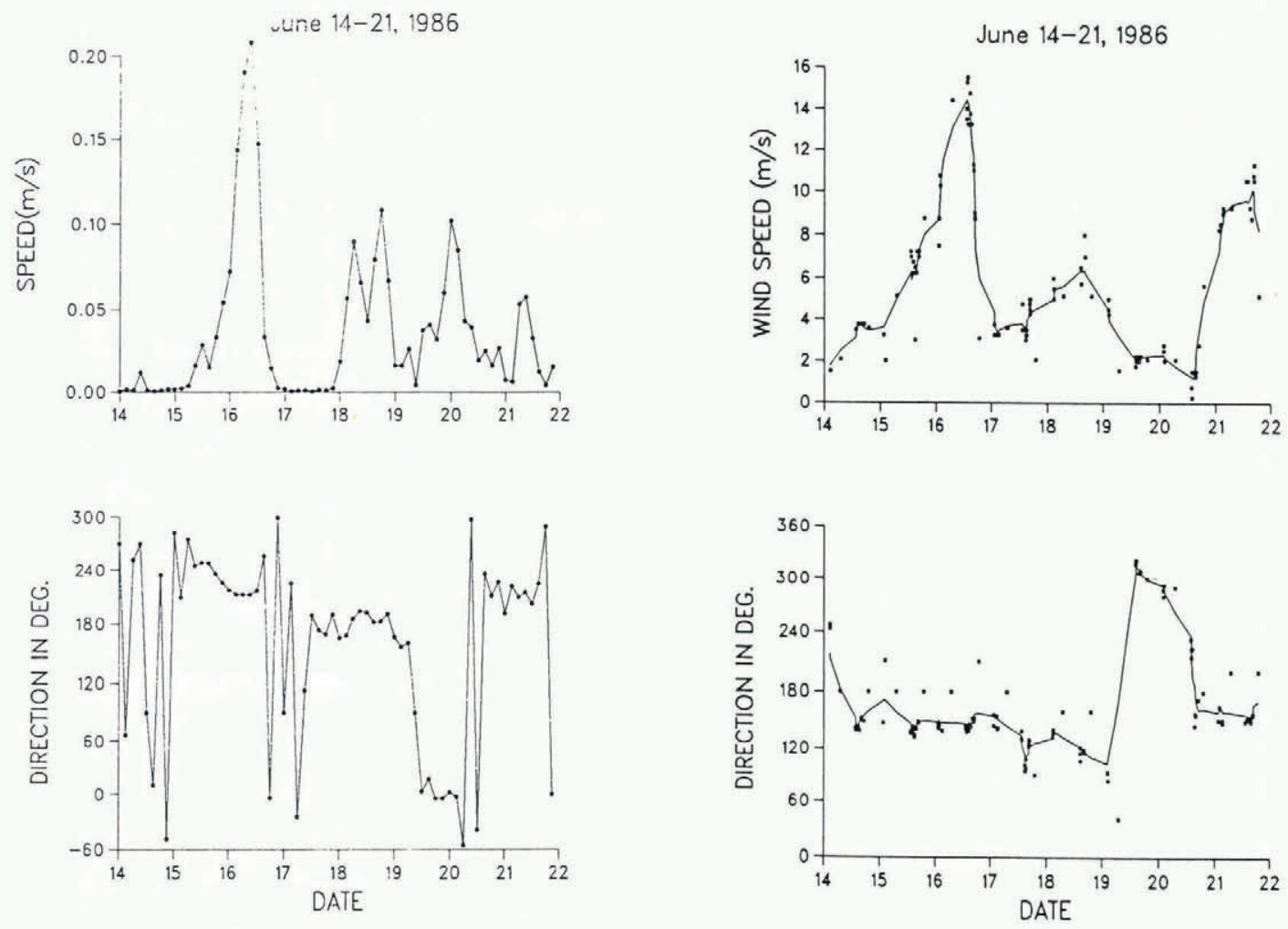

Fig. 4. Ice-island velocity and direction (left), compared with wind speed and direction (right), 14-21 June 1986.

After 16 May, no additional large movements took place, presumably because of a complete pack-ice coverage in the area. The surface-wind direction was from the north-west quadrant for the remainder of May 1986, and ice-island velocities were below $3.7 \mathrm{~cm} / \mathrm{s}$ during that time.

The next significant ice-island movement event was from 14 to 21 June 1986, during which a maximum iceisland speed of $20.8 \mathrm{~cm} / \mathrm{s}$ towards the north-east was reached (Fig. 4). Surface-wind direction was from the south-east quadrant and exceeded $6 \mathrm{~m} / \mathrm{s}$ at about 15.00 U.T. on 15 May. This apparently initiated the largest movement at this same time (Fig. 4). The peak value of ice-island velocity $(20.8 \mathrm{~cm} / \mathrm{s})$ was reached as the wind reached its peak value of $15 \mathrm{~m} / \mathrm{s}$. The ice-island velocity then dropped rapidly, from its peak value to less than $2 \mathrm{~cm} / \mathrm{s}$, in just $9 \mathrm{~h}$. Interestingly, the corresponding drop in wind speed lagged

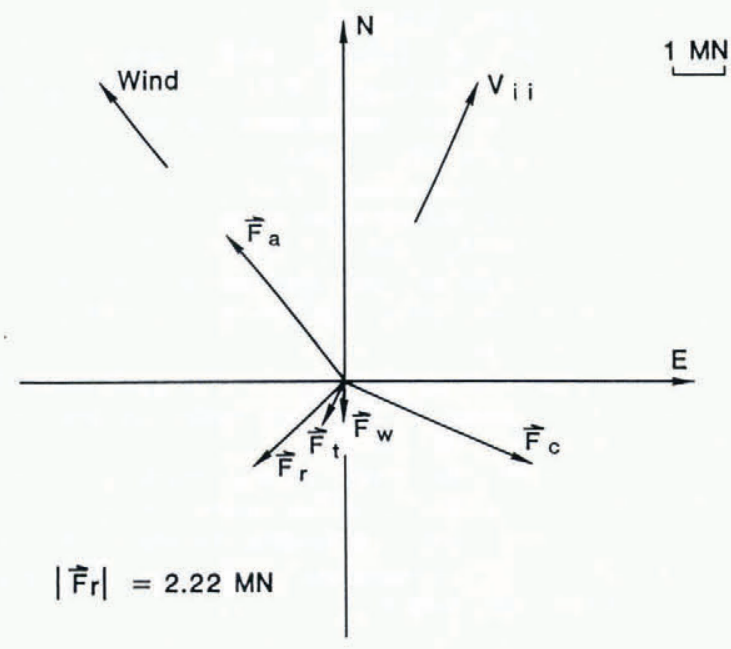

Fig. 5. Forces on ice island, and acceleration, 03.00 U.T., 8 May 1986. behind the island speed by about $6 \mathrm{~h}$, suggesting that a transient build-up of a substantial drag force, including a pack-ice component, was responsible. A maximum average deceleration of $13.6 \times 10^{-4} \mathrm{~cm} / \mathrm{s}^{2}$ was noted for the ice island. On 17 June, ice-island movement was minimal, with wind speeds of $3-5 \mathrm{~m} / \mathrm{s}$ from the south-east. From 18 June until 22 June, a sequence of periodic motions, perhaps of tidal origin, took place. Wind speeds were low until 21 June, when they reached $9-10 \mathrm{~m} / \mathrm{s}$ for a $12 \mathrm{~h}$ interval, again from the south-east quadrant. Wind from that direction apears to move the pack ice away from the coast, allowing appreciable ice-island motion in response to either wind or tidal currents. A wind-speed threshold of $6 \mathrm{~m} / \mathrm{s}$ seems to be a cause of wind-driven ice-island motion. A wind direction from the south-east quadrant seems to be a pre-condition for the several types of ice-island motion, which understandably would increase the density of open leads in the pack ice in the area, thus allowing more ice-island movement.

\section{DISCUSSION OF FORCES}

The force balance (including the acceleration term) acting upon the ice island at 03.00 U.T. on 8 May is shown in Figure 5. The residual calculated force attributed to pack ice and sea-surface tilt (which were not directly measured) is $2.2 \mathrm{MN}$, directed $158^{\circ}$ to the left of the direction of movement. This may be compared with steady drift results of Hunkins (1975), Yan (unpublished), and Sackinger and Tippens (1988), who found angles of $95-110^{\circ}$ for this pack-ice force direction.

A comparison of force balance for 03.00 U.T. and 12.00 U.T. on 16 June is given in Figure 6. Wind speed and direction, velocity, and Coriolis forces are similar, but a change from an accelerating to a decelerating condition took place because of a change in pack-ice force direction from $100^{\circ}$ to $180^{\circ}$ to the left of the direction of ice-island velocity. This is perhaps due to an accumulation of pack ice on the front edge of the ice island. Unfortunately, no pack-ice observations are available for this time to confirm this. 


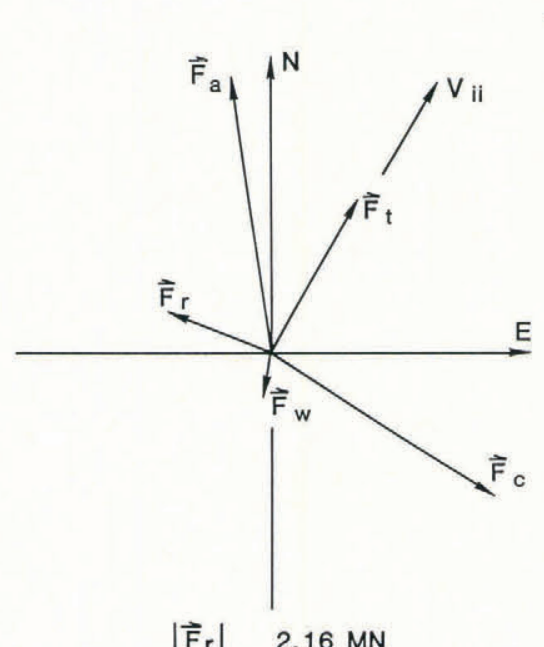

$\left|\overrightarrow{\mathrm{F}}_{\mathrm{r}}\right| \quad 2.16 \mathrm{MN}$
$1 \mathrm{MN}$

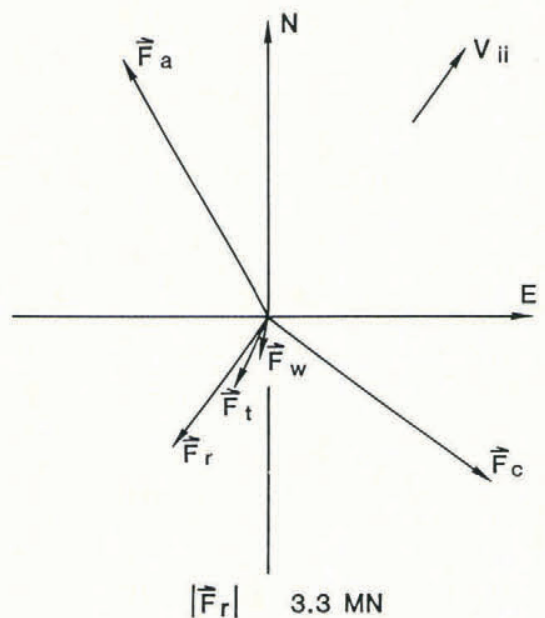

$\left|\overrightarrow{\mathrm{F}}_{\mathrm{r}}\right| \quad 3.3 \mathrm{MN}$

Fig. 6. Forces on ice island and acceleration for 03.00 U.T., 16 June 1986 (accelerating) and 12.00 U.T., 16 June 1986 (decelerating) conditions.

\section{CONCLUSIONS}

For the wind-driven ice-island movements near the coast of Axel Heiberg Island, ice-island movement is preceded by an offshore surface wind. For the ice-island movements analyzed, a threshold wind speed of about $6 \mathrm{~m} / \mathrm{s}$ was typical. Periodic movements, perhaps due to tidal currents, were noted after an offshore surface wind had reduced the pack-ice concentration near the coastline. An angle of $50^{\circ}$ was noted between surface wind and ice-island velocity for one wind-driven episode. The pack-ice force on the ice island varied, however, from $100^{\circ}$ to $180^{\circ}$ to the left of the island velocity, depending on the time within the wind-driven movement sequence. It is suggested that time-variable pack-ice accumulation in the vicinity of the ice island during the movement episodes is responsible for this behavior. Continued observation and analysis of the dynamics of Hobson's Ice Island is planned as the ice island drifts out of the High Arctic region and into other Arctic Ocean regions. Clearly, it is of interest to learn how this ice island and others behave in the coastal zones of the Canadian and Alaskan Beaufort Sea.

\section{ACKNOWLEDGEMENTS}

Support by the U.S. Department of Energy, Morgantown Energy Technology Center (contract No. DE-AC21-83MC20037), by the Canadian Polar Continental Shelf Project (G.D. Hobson, former Director), and by the Geophysical Institute, University of Alaska-Fairbanks (S.-I. Akasofu, Director), is gratefully acknowledged. Personal thanks are expressed to H. Serson, O.-P. Nordlund, and M. Schmidt.

\section{REFERENCES}

Browne, I.M. and A.P. Crary. 1958. The movement of ice in the Arctic Ocean. In Arctic Sea Ice Conference held at Easton, Maryland, February 24-27 1958. Washington, DC, National Academy of Sciences. National Research Council, 191-208. (Publ. 598.)

Hattersley-Smith, G. 1963. The Ward Hunt Ice Shelf: recent changes of the ice front. J. Glaciol., 4(34), 415-424.

Hunkins, K. 1967. Inertial oscillations of Fletcher's Ice Island (T-3). J. Geophys. Res., 72(4), 1165-1174.

Hunkins, K. 1975. The oceanic boundary layer and stress beneath a drifting ice floe. J. Geophys. Res., 80(24), 3425-3433.

Jeffries, M.O. 1986. Ice Island calvings and ice shelf changes, Milne Ice Shelf and Ayles Ice Shelf, Ellesmere Island, N.W.T. Arctic, 39(1), 15-19.

Jeffries, M.O. and H. Serson. 1983. Recent changes at the front of Ward Hunt Ice Shelf, Ellesmere Island, N.W.T. Arctic, 36(3), 289-290.

Jeffries, M.O., W.M. Sackinger, and H. Shoemaker. 1988. Geometry and physical properties of ice islands. In Sackinger, W.M. and M.O. Jeffries, eds. POAC 87; the 9 th International Conference on Port and Ocean Engineering under Arctic Conditions, Fairbanks, Alaska. Proceedings. Vol. I. Fairbanks, AK, University of Alaska. Geophysical Institute, 69-83.

Koenig, L.S., K.R. Greenaway, M. Dunbar, and G. Hattersley-Smith. 1952. Arctic ice islands. Arctic, 5(2), 67-103.

Langleben, M.P. 1982. Water drag coefficient of first year sea ice. J. Geophys. Res., 87(C1), 573-578.

McBean, G. 1986. The atmospheric boundary layer. In Untersteiner, N., ed. The geophysics of sea ice. New York and London, Plenum Press, 283-337. (NATO ASI Ser., Ser. B, Physics, 146.)

McPhee, M.G. 1982. Sea ice drag laws and simple boundary layer concepts, including application to rapid melting. CRREL Rep. 82-4.

Pease, C.H., S.A. Salo, and J.E. Overland. 1983. Drag measurements for first-year sea ice over a shallow sea. $J$. Geophys. Res., 88(C5), 2853-2862.

Sackinger, W.M. and H. Tippens. 1988. Analysis of ice island movement. In Sackinger, W.M. and M.O. Jeffries, eds. POAC 87; the 9th International Conference on Port and Ocean Engineering under Arctic Conditions, Fairbanks. Alaska. Proceedings. Vol. 1. Fairbanks, AK, University of Alaska. Geophysical Institute, 269-277.

Schmidt, M., J. Popelar, and J. Kouba. In press. Ice island 1985-86 navigation and geodetic positioning. Geol. Surv. Can. Open File. (Polar Continental Shelf Project. Ice Island Contribution 6.)

Shirasawa, K., N.P. Riggs, and D.B. Muggeridge. 1984. The drift of a number of idealized model icebergs. Cold Reg. Sci. Technol., 10(1), 19-30.

Spedding, L.G. 1986. Ice island count, southern Beaufort Sea. Report IPRT-13ME-77, APOA Project 99-3.

Yan, M. Unpublished. The relationship between ice island movement and weather conditions. (M.S. thesis, University of Alaska, Fairbanks, 1986.) 